\title{
PEMBANDINGAN DEFORMASI DAN GAYA INTERNAL DENGAN DAN TANPA INITIAL BOW IMPERFECTION PADA TOP DAN BOTTOM CHORD MENGGUNAKAN PEMODELAN ARCH TRUSS BRIDGE
}

\author{
Tri Widya Swastika ${ }^{(1)}$, Taztika Audea Putri ${ }^{(2)}$ \\ ${ }^{1}$ Dosen Jurusan Teknik Sipil, Politeknik Negeri Jakarta, Kampus UI Depok, Telp 021-7270036, email: \\ tri.widyaswastika@sipil.pni.ac.id \\ ${ }^{2}$ Alumni Jurusan Teknik Sipil, Politeknik Negeri Jakarta, Kampus UI Depok, Telp 021-7270036, email: \\ taztikaputri@gmail.com
}

\begin{abstract}
ABSTRAK
Imperfection adalah suatu keadaan saat elemen dari suatu struktur menekuk setelah dibebani (dalam batas toleransi yang dapat diterima) yang dapat terjadi akibat ketidak-lurusan suatu batang, adanya dimensi dan properti material yang bervariasi, residual stresses, adanya variasi boundary condition dan eksentrisitas pada sambungan. Namun sayangnya penelitian mengenai imperfection untuk memprediksi perilaku tekuk masih belum terlalu diperhatikan karena selama ini perilaku tekuk lebih kepada faktor kelangsingan padahal hal tersebut berpengaruh pada stabilitas suatu struktur. Sementara itu, arch truss bridge memerlukan analisis model yang lebih realistis terhadap struktur jembatan untuk menjaga keamanan dan kestabilan pada struktur jembatan. Pada penelitian ini bertujuan untuk mengetahui pembandingan deformasi dan gaya-gaya dalam pada pemodelan struktur arch truss bridge sebelum dan sesudah adanya imperfection untuk mengantisipasi ketidak-lurusan batang dari pabrik dan toleransi pelaksanaan dilapangan (initial imperfection). Pemodelan struktur arch truss bridge yang direncanakan dengan panjang total $100 \mathrm{~m}$, lebar $10 \mathrm{~m}$ dan tinggi $20 \mathrm{~m}$. Initial imperfection pada pemodelan struktur arch truss bridge dibagian top dan bottom pada bagian pelengkung jembatan merupakan initial bow imperfection yang diselesaikan dengan pemodelan langsung pola tekuk/ lendutan yang mungkin terjadi dari nilai precamber pada peraturan DIN 18800 part 2. Berdasarkan hasil pemodelan yang dilakukan dapat diketahui bahwa tipe in plane parabolic down menghasilkan perbedaan terbesar antara sebelum dan sesudah initial bow imperfection, pada hasil persentase terhadap deformasi sebesar $1,97 \%$, gaya aksial sebesar $0,78 \%$, dan bending moment sebesar $0,69 \%$.
\end{abstract}

Kata kunci: Initial Bow Imperfection, Arch Truss Bridge, Pre-Camber, Deformasi, Bending Moment

\begin{abstract}
Imperfection is a condition when the buckling occur after loaded (within acceptable tolerances) in the frame of a structure. Imperfection can occur because of out of straightness member, variances in dimensional and material properties, residual stresses, variances in boundary condition and eccentricities at joints. Unfortunately, research about imperfection to predict buckling behaviour is still neglected. Meanwhile, an arch truss bridge requires a more realistic model analysis for bridge structure to maintain safety and stability. The purpose of this research is to compare the deformation and internal forces in the modeling of an arch truss bridge structure before and after initial bow imperfection to anticipate member from out of straightness from fabrication and tolerance implementation on site (initial imperfection). The model of arch truss bridge structure is planned to have a total span of length 100 meters, $20 \mathrm{~m}$ width, and $20 \mathrm{~m}$ height. Initial imperfection in modeling implemented at the top and bottom the bridge arch section is initial bow imperfection which is solved by direct modeling/ deflection that might occur from pre-camber value, stated in DIN 18800 part-2. Based on the results of the model, the in plane parabolic down type produces the biggest difference between before and after initial bow imperfection. The percentage result of displacement about 1,97\%, axial force exactly 0,78\%, and 0,69\% of bending moment.
\end{abstract}

Keywords: Initial Bow Imperfection, Arch Truss Bridge, Pre-Camber, Deformation, Bending Moment 


\section{PENDAHULUAN}

Stabilitas adalah hal penting pada perencanaan struktur baja, dan harus ditinjau secara keseluruhan, baik sebagai struktur (global), atau sebagai elemen-elemen penyusunnya (lokal). Dalam memperhitungkan stabilitas, perlu dimasukkan juga faktor-faktor yang mempengaruhi, yaitu deformasi elemen akibat momen lentur, gaya aksial atau gaya geser, juga bentuk deformasi lain yang dapat mempengaruhi perilaku struktur. Pengaruh orde-2 (non linier geometri), baik P- $\Delta$ (global - struktur) atau P- $\delta$ (lokal - elemen), ketidak-sempurnaan geometri (geometry imperfection), reduksi penampang akibat kondisi inelastic, dan ketidak-pastian kekuatan dan kekakuan perencanaan. (AISC, 2010).

Perhitungan stabilitas struktur modern didasarkan anggapan bahwa perhitungan gayagaya batang diperoleh dari analisa struktur elastik orde-2, yang memenuhi kondisi keseimbangan setelah pembebanan, yaitu setelah deformasi. Ketidak-sempurnaan dari elemen struktur, seperti ketidak-lurusan suatu batang akibat proses fabrikasi atau konsekuensi adanya toleransi pelaksanaan lapangan, akan menghasilkan apa yang disebut efek destabilizing. Adanya cacat bawaan (initial imperfection) yang mengakibatkan efek destablizing dapat diselesaikan dengan dua cara, yaitu [1] cara pemodelan langsung cacat pada geometri model yang dianalisis, atau [2] memberikan beban notional (beban lateral ekivalen) dari sebagian prosentasi beban gravitasi yang bekerja. Cara pemodelan langsung dapat diberikan pada titik nodal batang yang digeser untuk sejumlah tertentu perpindahan, yang besarnya diambil dari toleransi maksimum yang diperbolehkan dalam perencanaan maupun pelaksanaan. Pola penggeseran titik nodal pada pemodelan langsung harus dibuat sedemikian rupa sehingga memberikan efek destabilizing terbesar.

Pola yang dipilih dapat mengikuti pola lendutan hasil pembebanan atau pola tekuk yang mungkin terjadi. (Wiryanto, 2014). Didalam DIN 18800 part 2 mengenai imperfection dapat diketahui bahwa cara pemodelan langsung cacat pada geometri model yang dianalisis dinamakan initial bow imperfection sedangkan cara pemberian beban notional (beban lateral ekivalen) dari sebagian prosentasi beban gravitasi yang bekerja disebut initial sway imperfection. Walaupun imperfection merupakan perhitungan stabilitas modern untuk memprediksi perilaku tekuk, namun penelitian mengenai hal tersebut masih belum terlalu diperhatikan karena selama ini perilaku tekuk lebih kepada faktor kelangsingan. Pada Arch Truss Bridge, bagian top dan bottom pada bagian pelengkungnya lebih beresiko terjadi ketidak-lurusan batang akibat proses pabrikasi atau akibat pelaksanaan perakitan jembatan dilapangan maupun dipabrik (trial assembly). Oleh sebab itu, sangat perlu memperhitungkan initial imperfection untuk mengantisipasi keadaan tersebut.

\section{METODE PENELITIAN}

Metode perancangan ini akan menjelaskan tahapan-tahapan memodelkan jembatan busur rangka dengan memberikan pengaruh initial bow imperfection pada top dan bottom chord struktur dari nilai pre camber. 


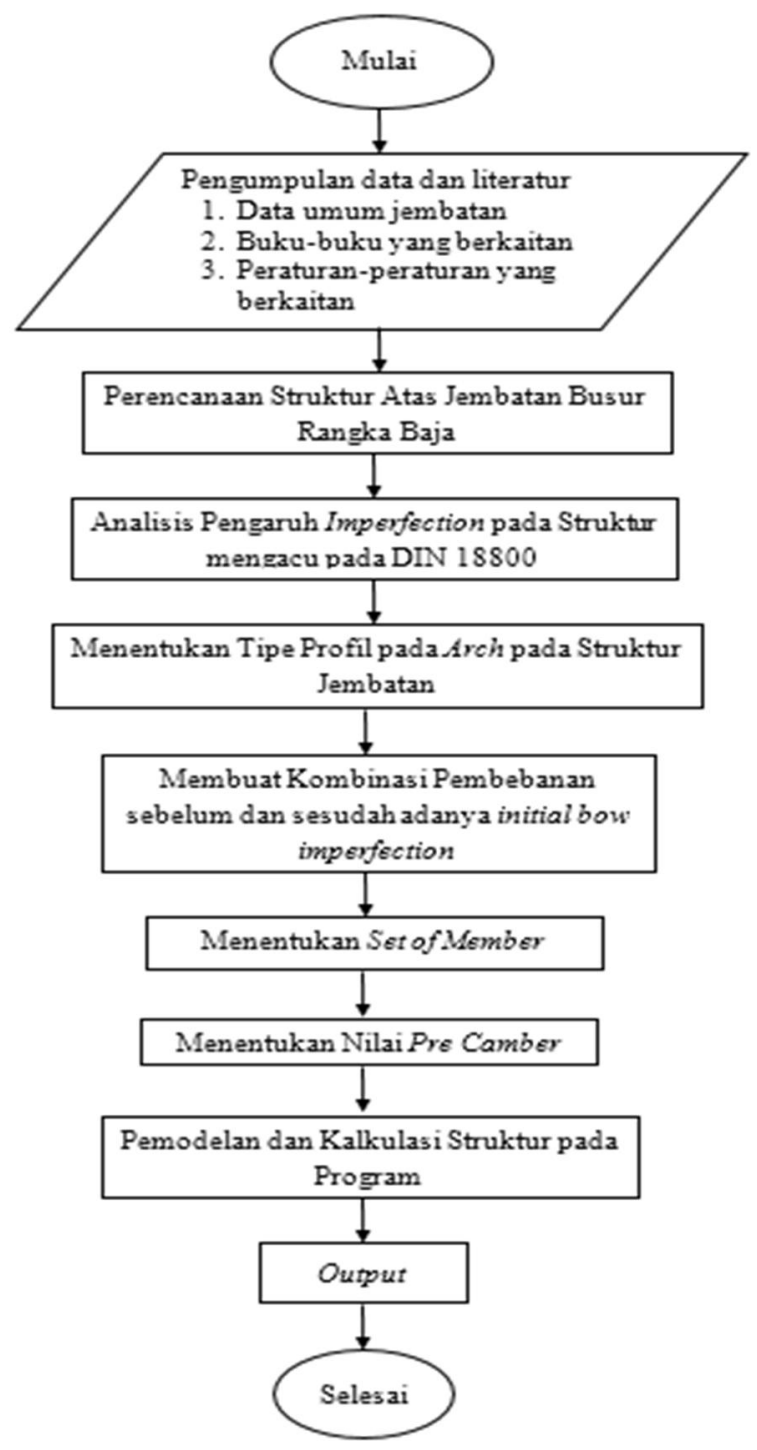

Gambar 1. Bagan Alir Penelitian

\section{HASIL DAN PEMBAHASAN}

Pada SNI 1725-2016 terdapat lima kombinasi pembebanan untuk jembatan seperti terdapat pada Tabel 1, pada masing-masing kombinasi tersebut diberikan enam pola imperfection seperti pada Tabel 2.

Tabel 1. Kombinasi Pembebanan Jembatan

\begin{tabular}{cc}
\hline NO. & KOMBINASI \\
\hline 1. & ULS : Self Weight + DL + LL + Rem + Temperatur \\
2. & ULS : Self Weight + DL + LL + Rem + Temperatur \\
3. & ULS : Self Weight + DL + LL + Angin Vertikal + Temperatur \\
4. & ULS : Self Weight + DL + LL + Temperatur \\
5. & ULS : Self Weight + DL + LL + Rem + Angin Vertikal + Angin \\
& Kendaraan + Temperatur \\
\hline
\end{tabular}


Tabel 2. Tipe Imperfection Menurut Peraturan DIN 18800

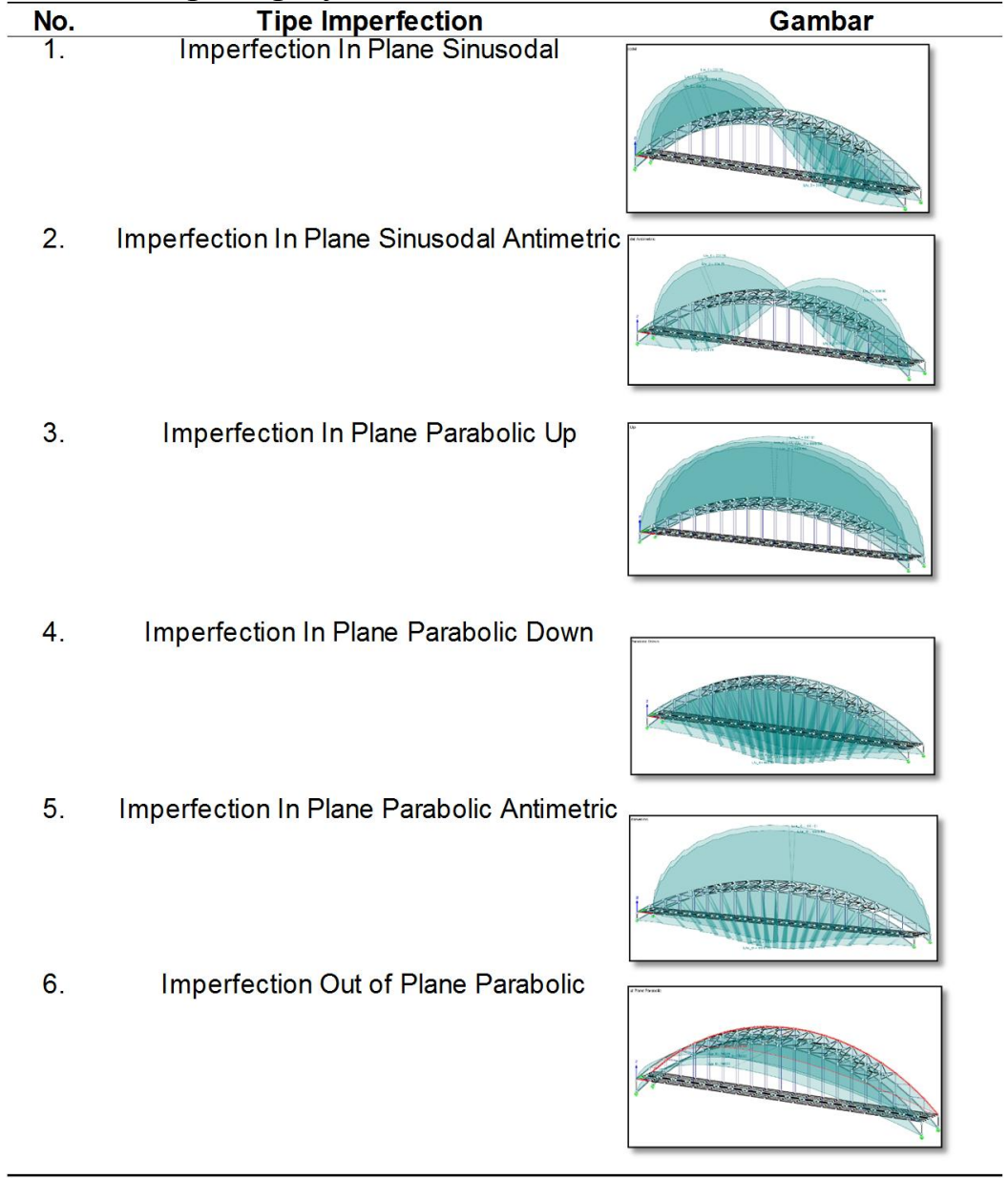

\subsection{Deformasi}

\subsubsection{Kombinasi 1}

Pada Gambar 2a terdapat grafik deformasi terbesar akibat kombinasi 1. Peningkatan deformasi terbesar terjadi pada pola tekuk in plane parabolic down yaitu sebesar 593,11 $\mathrm{mm}$ sedangkan peningkatan deformasi terkecil terjadi pada pola tekuk out of plane parabolic yaitu sebesar $583,67 \mathrm{~mm}$.

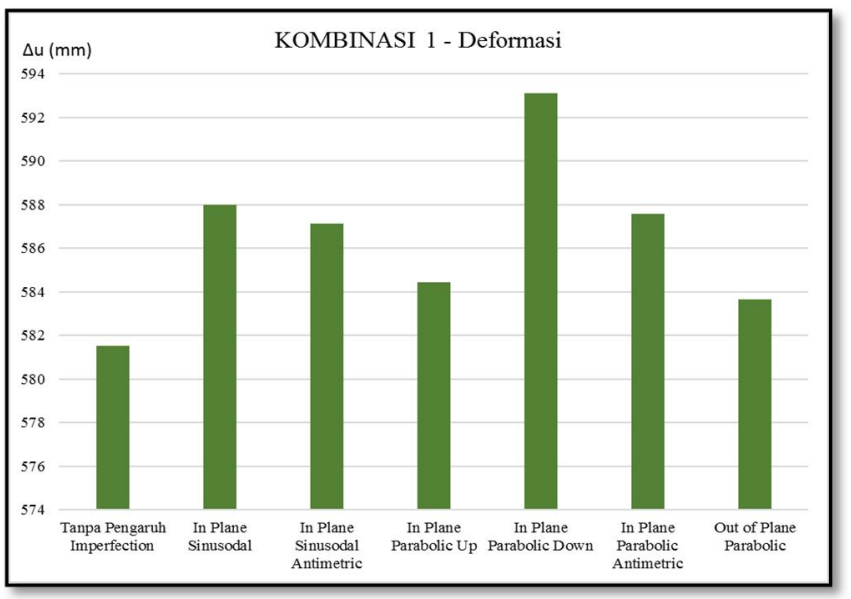

Gambar 2a. Grafik Deformasi Kombinasi 1 


\subsubsection{Kombinasi 2}

Pada Gambar 2b terdapat grafik deformasi terbesar akibat kombinasi 2. Peningkatan deformasi terbesar terjadi pada pola tekuk in plane parabolic down yaitu sebesar 596,26 mm sedangkan peningkatan deformasi terkecil terjadi pada pola tekuk out of plane parabolic yaitu sebesar $586,77 \mathrm{~mm}$.

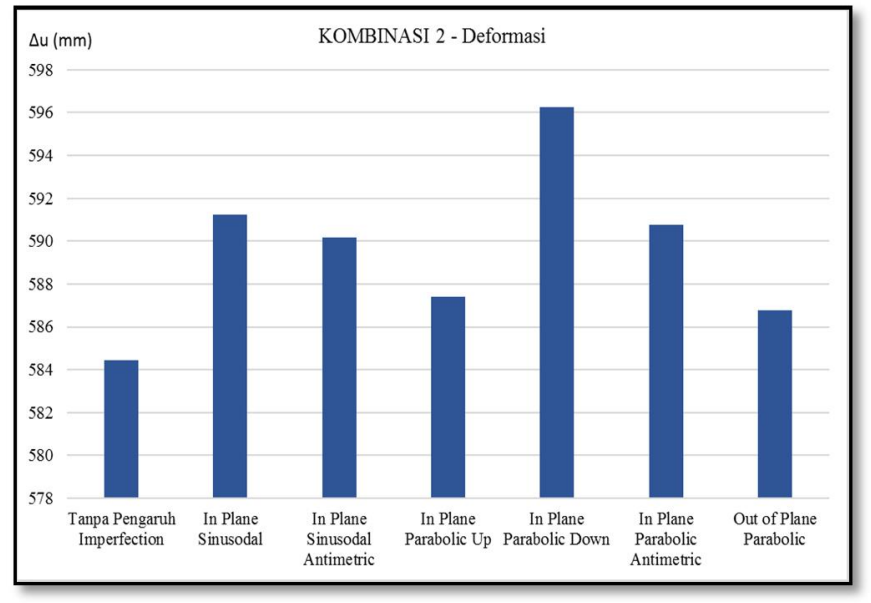

Gambar 2b. Grafik Deformasi Kombinasi 2

\subsubsection{Kombinasi 3}

Pada Gambar 2c terdapat grafik deformasi terbesar akibat kombinasi 3. Peningkatan deformasi terbesar terjadi pada pola tekuk in plane parabolic down yaitu sebesar 506,54 $\mathrm{mm}$ sedangkan peningkatan deformasi terkecil terjadi pada pola tekuk out of plane parabolic yaitu sebesar 498,54 $\mathrm{mm}$.

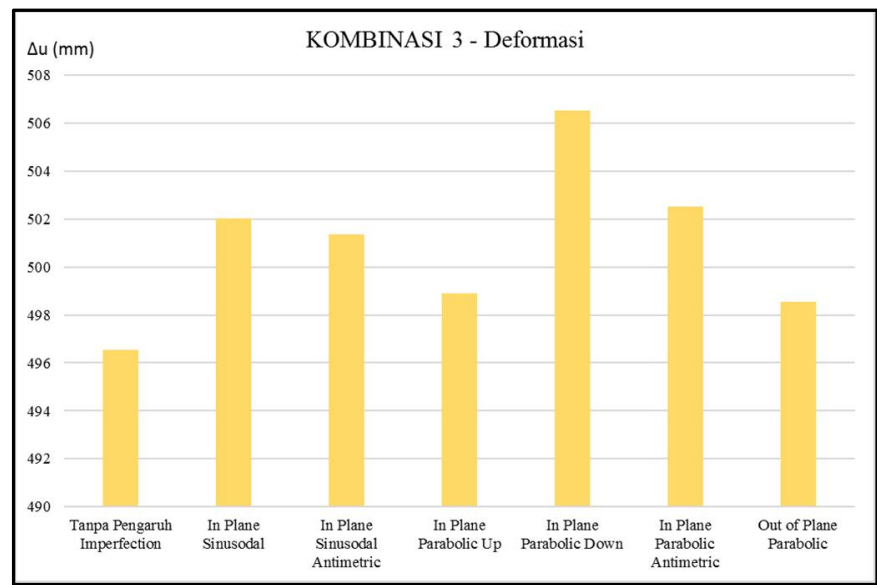

Gambar 2c. Grafik Deformasi Kombinasi 3

\subsubsection{Kombinasi 4}

Pada Gambar 2d terdapat grafik deformasi terbesar akibat kombinasi 4. Peningkatan deformasi terbesar terjadi pada pola tekuk in plane parabolic down yaitu sebesar 494,31 mm sedangkan peningkatan deformasi terkecil terjadi pada pola tekuk out of plane parabolic yaitu sebesar $488,64 \mathrm{~mm}$. 


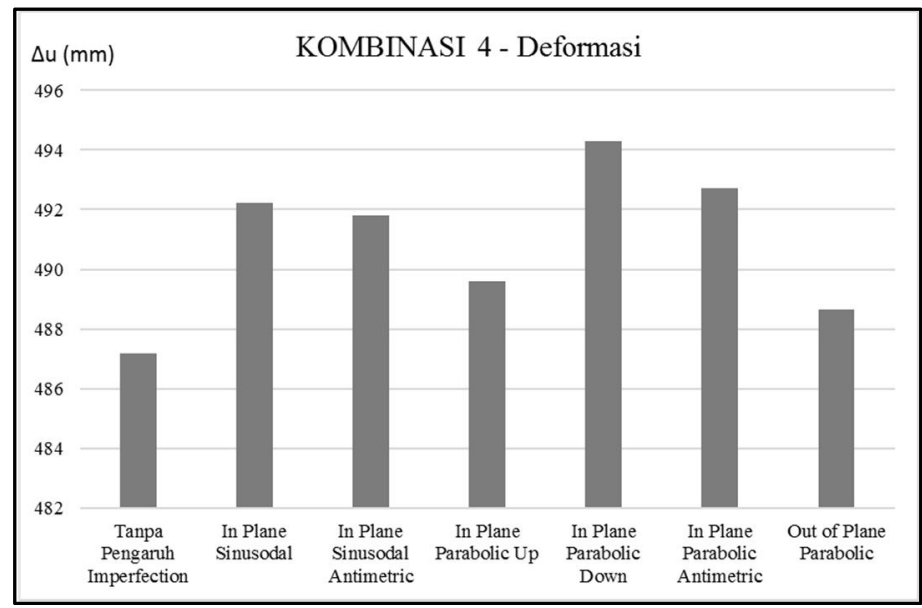

Gambar 2d. Grafik Deformasi Kombinasi 4

\subsubsection{Kombinasi 5}

Pada Gambar 2e terdapat grafik deformasi terbesar akibat kombinasi 5. Peningkatan deformasi terbesar terjadi pada pola tekuk in plane parabolic down yaitu sebesar 593,74 mm sedangkan peningkatan deformasi terkecil terjadi pada pola tekuk parabolic up yaitu sebesar 582,68 $\mathrm{mm}$.

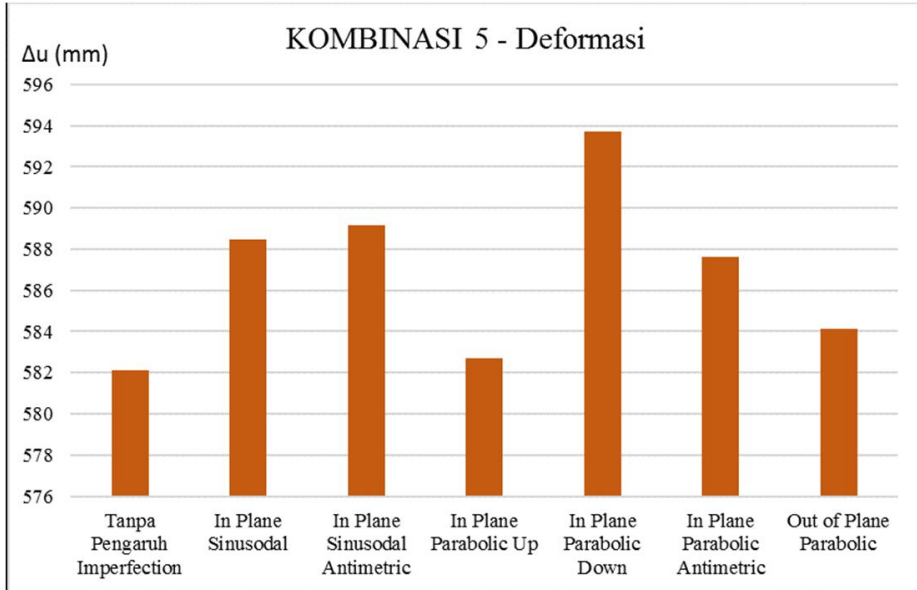

Gambar 2e. Grafik Deformasi Kombinasi 5

\subsection{Gaya Aksial}

\subsubsection{Kombinasi 1}

Pada Gambar 3a terdapat grafik gaya aksial terbesar akibat kombinasi 1. Peningkatan gaya aksial terbesar terjadi pada pola tekuk in plane parabolic down yaitu sebesar $7927,37 \mathrm{kN}$ sedangkan peningkatan gaya aksial terkecil terjadi pada pola tekuk sinusodal antimetric yaitu sebesar 7880,97 kN. 


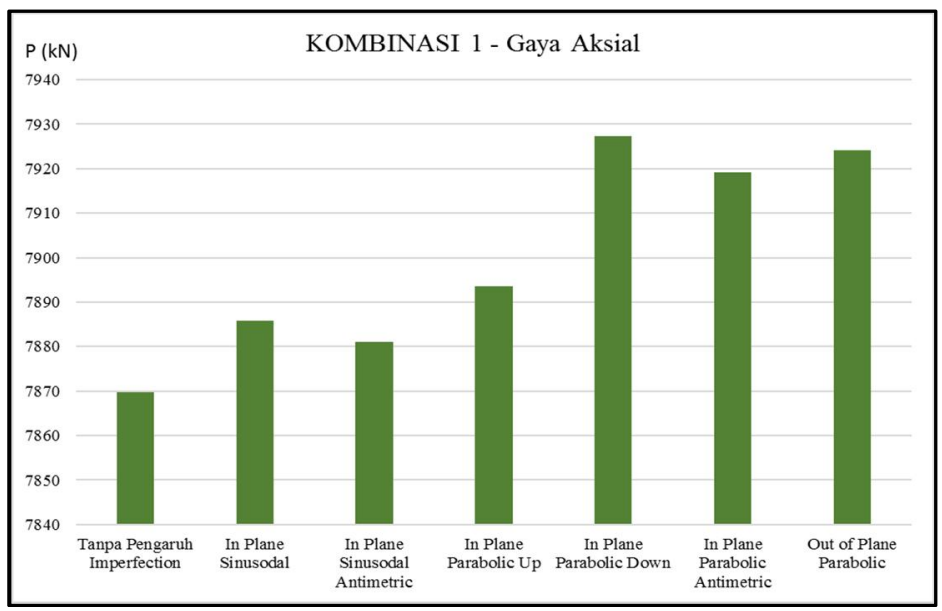

Gambar 3a. Grafik Gaya Aksial Kombinasi 1

\subsubsection{Kombinasi 2}

Pada Gambar 3b terdapat grafik gaya aksial terbesar akibat kombinasi 2. Peningkatan gaya aksial terbesar terjadi pada pola tekuk in plane parabolic down yaitu sebesar $8014,37 \mathrm{kN}$ sedangkan peningkatan gaya aksial terkecil terjadi pada pola tekuk sinusodal antimetric yaitu sebesar $7965,88 \mathrm{kN}$.

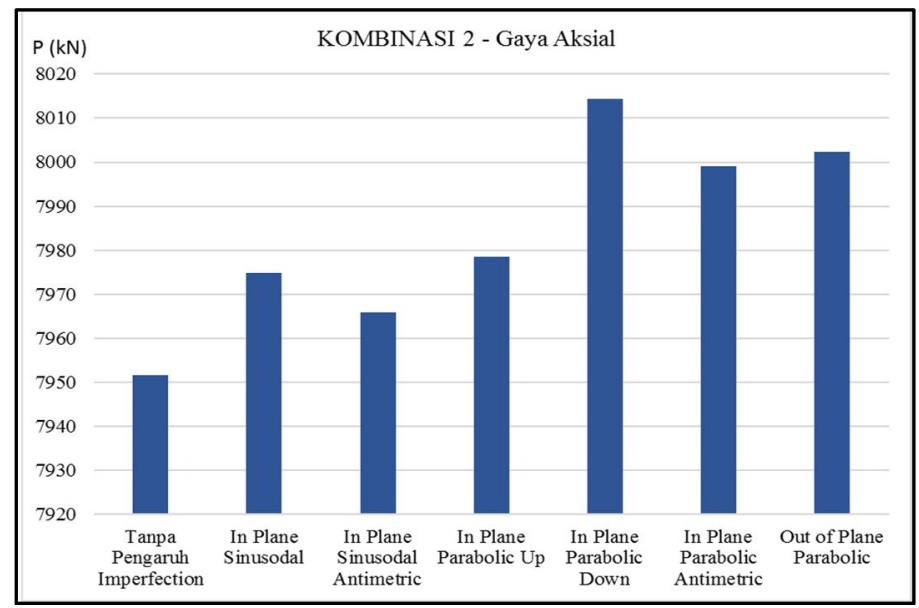

Gambar 3b. Grafik Gaya Aksial Kombinasi 2

\subsubsection{Kombinasi 3}

Pada Gambar 3c terdapat grafik gaya aksial terbesar akibat kombinasi 3. Peningkatan gaya aksial terbesar terjadi pada pola tekuk in plane parabolic down yaitu sebesar $5525,63 \mathrm{kN}$ sedangkan peningkatan gaya aksial terkecil terjadi pada pola tekuk sinusodal antimetric yaitu sebesar 5496,35

\subsubsection{Kombinasi 4}

Pada Gambar 3d terdapat grafik gaya aksial terbesar akibat kombinasi 4. Peningkatan gaya aksial terbesar terjadi pada pola tekuk in plane parabolic down yaitu sebesar $5524,09 \mathrm{kN}$ sedangkan peningkatan gaya aksial terkecil terjadi pada pola tekuk sinusodal antimetric yaitu sebesar 5486,91 kN. 


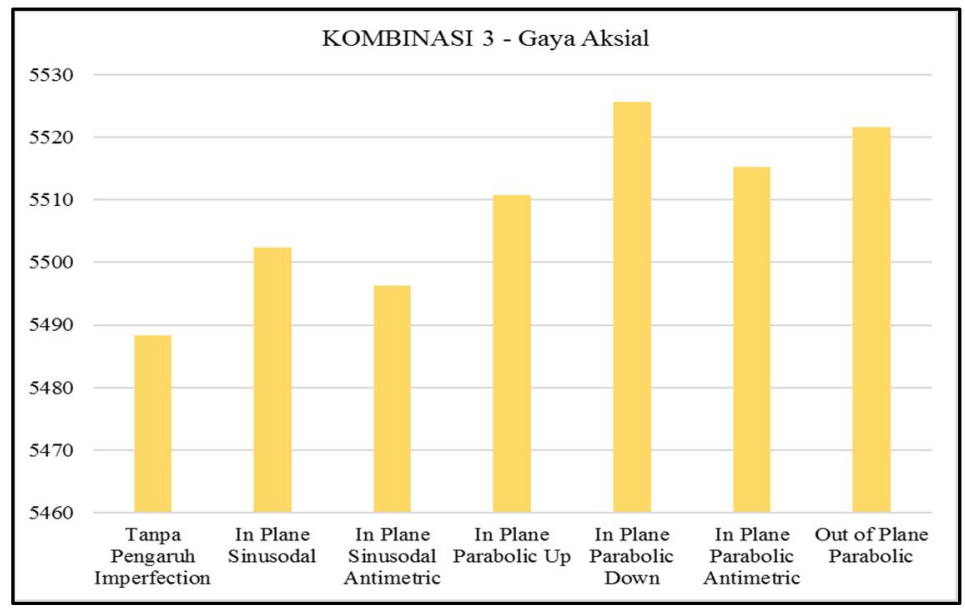

Gambar 3c. Grafik Gaya Aksial Kombinasi 3

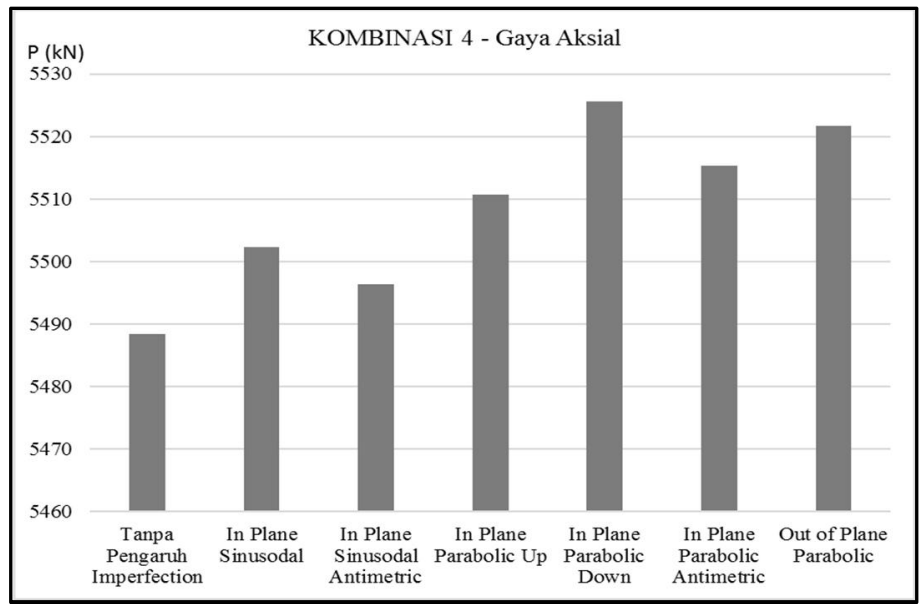

Gambar 3d. Grafik Gaya Aksial Kombinasi 4

\subsubsection{Kombinasi 5}

Pada Gambar 3e terdapat grafik gaya aksial terbesar akibat kombinasi 5. Peningkatan gaya aksial terbesar terjadi pada pola tekuk in plane parabolic down yaitu sebesar $7535,55 \mathrm{kN}$ sedangkan peningkatan gaya aksial terkecil terjadi pada pola tekuk sinusodal antimetric yaitu sebesar 7494,64 kN.

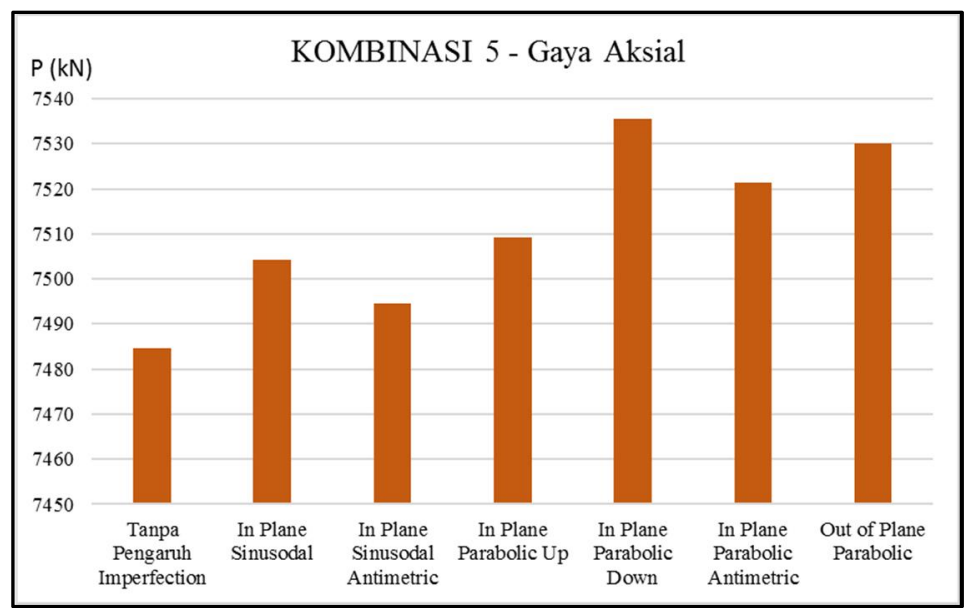

Gambar 3e. Grafik Gaya Aksial Kombinasi 5 


\subsection{Bending Moment}

\subsubsection{Kombinasi 1}

Pada Gambar 4a terdapat grafik gaya aksial terbesar akibat kombinasi 1. Peningkatan deformasi terbesar terjadi pada pola tekuk in plane parabolic down yaitu sebesar 309,94 $\mathrm{kN}$ sedangkan peningkatan deformasi terkecil terjadi pada pola tekuk parabolic up yaitu sebesar 308,41 kN.

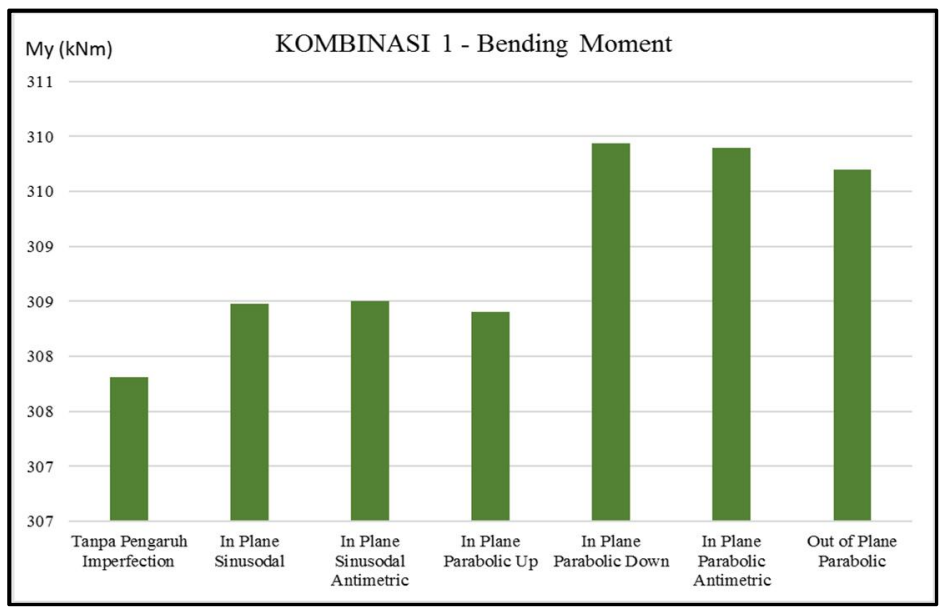

Gambar 4a. Grafik Bending Moment Kombinasi 1

\subsubsection{Kombinasi 2}

Pada Gambar 4b terdapat grafik gaya aksial terbesar akibat kombinasi 2. Peningkatan deformasi terbesar terjadi pada pola tekuk in plane parabolic down yaitu sebesar 315,42 $\mathrm{kN}$ sedangkan peningkatan deformasi terkecil terjadi pada pola tekuk parabolic up yaitu sebesar $313,74 \mathrm{kN}$.

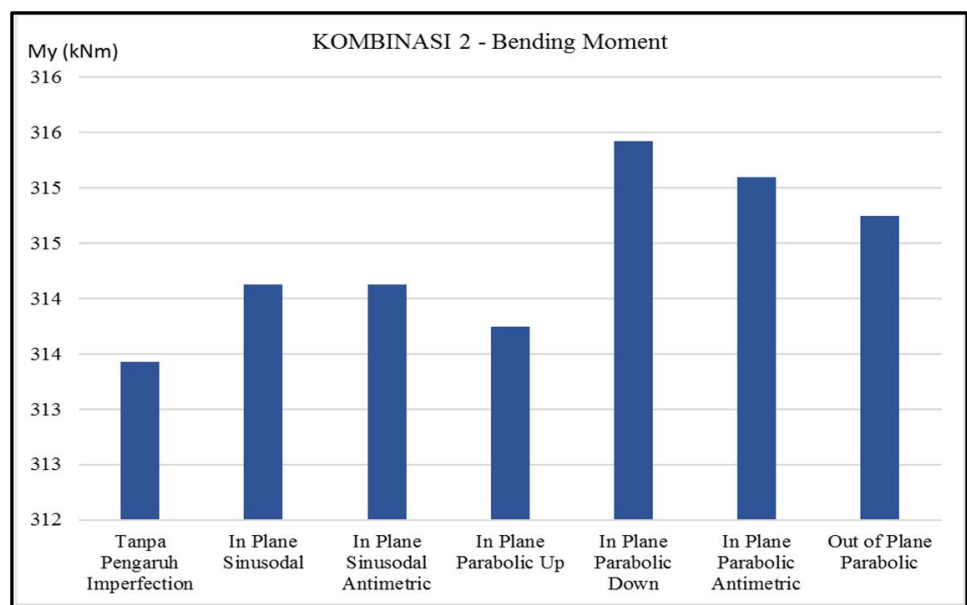

Gambar 4b. Grafik Bending Moment Kombinasi 2

\subsubsection{Kombinasi 3}

Pada Gambar 4c terdapat grafik gaya aksial terbesar akibat kombinasi 3. Peningkatan deformasi terbesar terjadi pada pola tekuk in plane parabolic down yaitu sebesar 288,29 $\mathrm{kN}$ sedangkan peningkatan deformasi terkecil terjadi pada pola tekuk parabolic up yaitu sebesar $287,26 \mathrm{kN}$. 


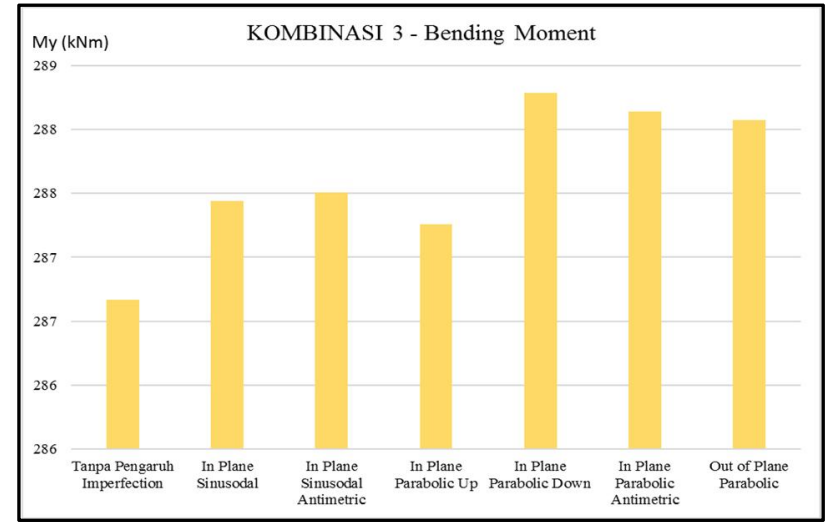

Gambar 4c. Grafik Bending Moment Kombinasi 3

\subsubsection{Kombinasi 4}

Pada Gambar 4d terdapat grafik gaya aksial terbesar akibat kombinasi 4. Peningkatan deformasi terbesar terjadi pada pola tekuk in plane parabolic down yaitu sebesar 277,04 $\mathrm{kN}$ sedangkan peningkatan deformasi terkecil terjadi pada pola tekuk parabolic up yaitu sebesar 275,96 kN.

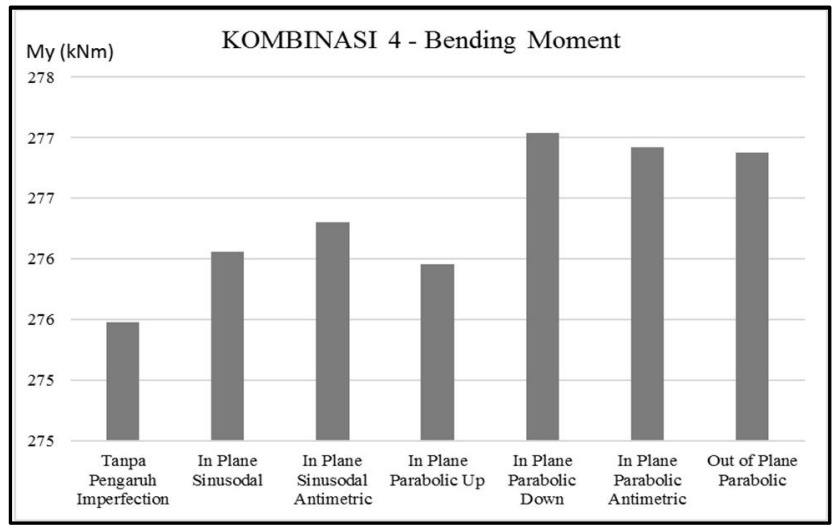

Gambar 4d. Grafik Bending Moment Kombinasi 4

\subsubsection{Kombinasi 5}

Pada Gambar 4e terdapat grafik gaya aksial terbesar akibat kombinasi 5. Peningkatan deformasi terbesar terjadi pada pola tekuk in plane parabolic down yaitu sebesar 348,12 $\mathrm{kN}$ sedangkan peningkatan deformasi terkecil terjadi pada pola tekuk parabolic up yaitu sebesar $347,47 \mathrm{kN}$.

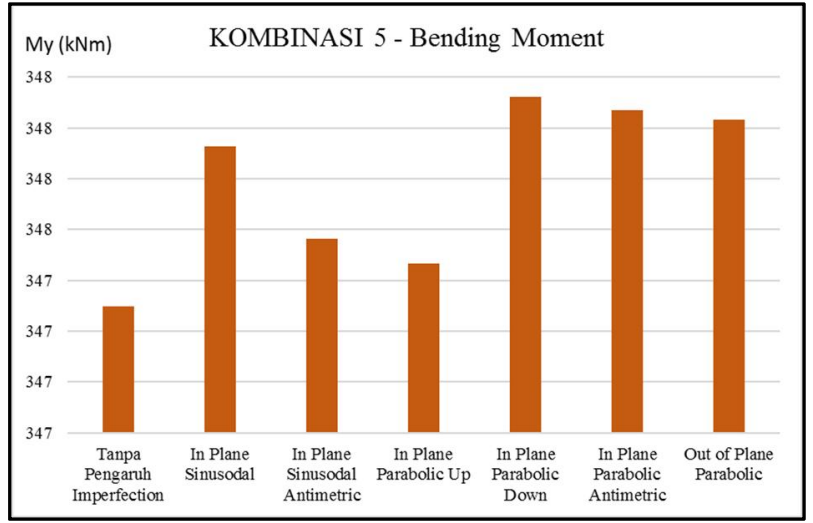

Gambar 4e. Grafik Bending Moment Kombinasi 5 


\subsection{Hasil Perbandingan Sebelum dan Sesudah adanya Initial Bow Imperfection}

\subsubsection{Deformasi}

Pada Gambar 5 terdapat grafik nilai maksimum dari bending moment untuk lima kombinasi pembebanan pada jembatan. Grafik tersebut menunjukkan bahwa pola tekuk/ pola lendutan yang memberikan efek peningkatan bending moment terbesar pada struktur jembatan adalah tipe in plane parabolic down yaitu sebesar $315,42 \mathrm{kNm}$, sedangkan efek peningkatan gaya aksial terkecil pada jenis pola tekuk/ pola lendutan adalah tipe parabolic up yaitu sebesar $313,74 \mathrm{kNm}$. Nilai peningkatan yang terbesar dan terkecil terjadi pada kombinasi pembebanan ke dua yaitu terdiri dari beban mati, beban mati tambahan, beban hidup, dan beban temperatur.

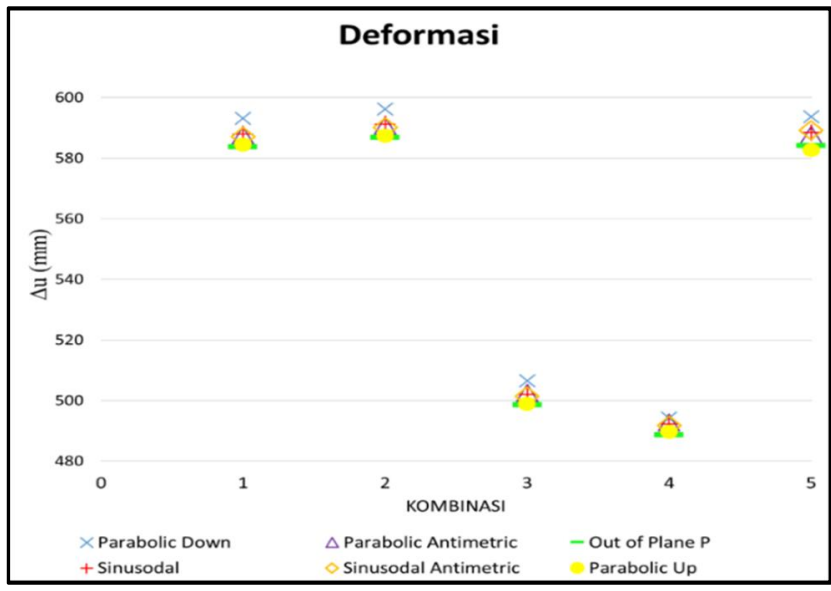

Gambar 5. Grafik Perbandingan Deformasi Pada Struktur Jembatan

\subsubsection{Gaya Aksial}

Pada Gambar 6 terdapat grafik nilai maksimum dari gaya aksial untuk lima kombinasi pembebanan pada jembatan. Grafik tersebut menunjukkan bahwa pola tekuk/ pola lendutan yang memberikan efek peningkatan gaya aksial terbesar pada struktur jembatan adalah tipe in plane parabolic down yaitu sebesar $8014,37 \mathrm{kN}$, sedangkan efek peningkatan gaya aksial terkecil pada jenis pola tekuk/ pola lendutan adalah tipe sinusodal antimetric yaitu sebesar $7965,88 \mathrm{kN}$. Nilai peningkatan yang terbesar dan terkecil terjadi pada kombinasi pembebanan ke dua yaitu terdiri dari beban mati, beban mati tambahan, beban hidup, dan beban temperatur.

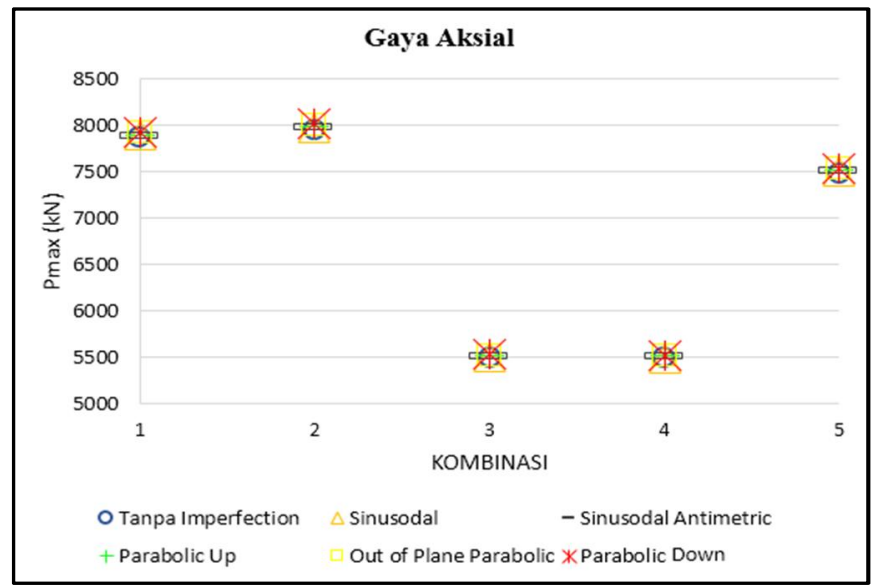

Gambar 6. Grafik Perbandingan Gaya Aksial Pada Struktur Jembatan 


\subsubsection{Bending Moment}

Pada Gambar 7 terdapat grafik nilai maksimum dari bending moment untuk lima kombinasi pembebanan pada jembatan. Grafik tersebut menunjukkan bahwa pola tekuk/ pola lendutan yang memberikan efek peningkatan bending moment terbesar pada struktur jembatan adalah tipe in plane parabolic down yaitu sebesar $315,42 \mathrm{kNm}$, sedangkan efek peningkatan gaya aksial terkecil pada jenis pola tekuk/ pola lendutan adalah tipe parabolic up yaitu sebesar $313,74 \mathrm{kNm}$. Nilai peningkatan yang terbesar dan terkecil terjadi pada kombinasi pembebanan ke dua yaitu terdiri dari beban mati, beban mati tambahan, beban hidup, dan beban temperatur.

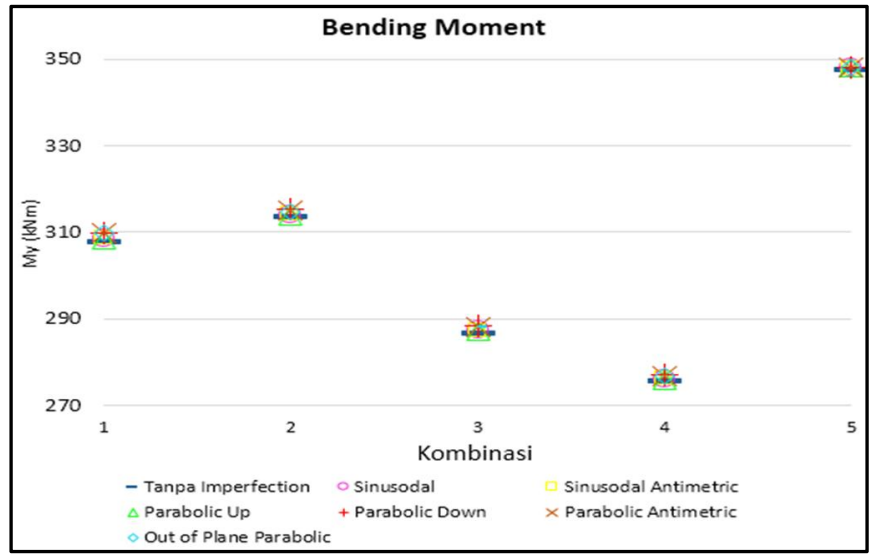

Gambar 7. Grafik Perbandingan Bending Moment Pada Struktur Jembatan

\section{KESIMPULA11N}

Hasil pemodelan pada struktur jembatan busur rangka baja menunjukan bahwa terdapat pengaruh peningkatan terbesar sebelum dan sesudah adanya initial bow imperfection yaitu pada tipe pola tekuk/ pola lendutan in plane parabolic down. Pada hasil pemodelan memiliki hasil peningkatan terbesar terhadap deformasi sebesar $1,97 \%$, gaya aksial sebesar $0,78 \%$, dan bending moment sebesar $0,69 \%$.

\section{DAFTAR PUSTAKA}

[1] Dewobroto, Wiryanto (2015). Struktur Baja: Perilaku, Analisis \& Desain -AISC 2010. Jakarta: Lumina Press.

[2] DIN 18800 (1995). Structural Steelwork Safety Against Buckling of Linear member and frames. Jerman : Beuth Verlag.

[3] Standar Nasional Indonesia. (2004). RSNI -T-12-2004 (Perencanaan Struktur Beton Untuk Jembatan). Jakarta: Badan Standarisasi Nasional.

[4] Standar Nasional Indonesia. (2005). RSNI -T-03-2005 (Perencanaan Struktur Baja Untuk Jembatan). Jakarta: Badan Standarisasi Nasional.

[5] Standar Nasional Indonesia. (2016). SNI 1725-2016 (Pembebanan Untuk Jembatan). Jakarta: Badan Standarisasi Nasional.

[6] J.F.Fleming, J. D. Zenk, B Vethiyavevorn (1979), Static And Seismic Analysis Of Cable Stayed Bridge. Journal Indian Institute of Technolgy, Vol. 10, pp 621-635.

[7] Wen-Liang Qiu, Chin S. K., Chang H. K., Jeng L. Tsai., \& Guang Y. (2010). Stability Analysis of Special-Shape Arch Bridge. Tamkang Journal of Science and Engineering, Volume 13, No 4, pp 365-373. 